So far is it from being true that I have represented hovering as an accomplishment of wingmanship which requires little exertion, that I have asserted with emphasis the exactly opposite doctrine-that it is a specially difficult operation, requiring very often great exertion, and always requiring special muscular effort.

It is evident, however, that Mr. Guthrie is still ignorant of the facts which have to be explained. In the passage which he misquotes I am not stating any theory; I am stating a fact which I have seen over and over again. It is a fact beyond ail question that a kestrel can maintain itself hovering in a strong horizontal air-current, with no other muscular exertion than that which is required to keep its wings and body at th right angle. I have seen it done a hundred times in level countries, when by no possibility could any upward deflection of the wind have arisen from the configuration of the ground.

One of the first and most fundamental facts to be admitted and accounted for in the flight of birds is, that perfectly horizontal air-currents have a powerfully sustaining effect upon vane surfaces, which are presented to them as birds' wings are presented. "Hovering" and "soaring" are only to be explained when this fact is seen and admitted.

Inverary, Argyllshire, July 30

\section{Exhibition of Specimens and Apparatus at British Association Meetings}

I AM anxious to draw the attention of the readers of NATURE to the arrangements to be made this year at the British Association meeting (for the first time) for the reception of specimens and apparatus illustrating papers or short communications made to the sections. The provision of a room for this purpose-a kind of temporary museum--has during the last four years been recommended by the committees of Sections $\mathrm{C}$ and $\mathrm{D}$, several times, and this year the experiment is to be made. Those who have promoted this plan are naturally anxious that it should be a success. I would therefore appeal to the secretaries of the various sections to assist in initiating this new feature of the meeting, by endeavouring, as far as possible, to secure from the authors of papers objects which illustrate their communications ; such objects to be deposited during the week of meeting in the room provided by the Council. This room will be open to inspection under the same regulations as the sectional meeting rooms, and the objects deposited will be carefully ticketed and arranged, and, where necessary, placed under glass cases.

From Section A we may expect physical and astronomical apparatus and models; from $B$, new chemical products and specimens of apparatus illustrating new processes; from $C$, geological specimens of rarity or new to science; from D, zoological and botanical specimens, anatomical preparations, for the exhibition of which microscopes will be provided, and also ethnological specimens; from E, maps and geographical models; from $F$ and $G$, models or machinery not too large for a room.

It is necessary to mention that objects exhibited must be in illustration of some communication (however short) to one of the sections, in order that they may thus be sanctioned by the committee of such section.

By the co-operation of the sectional secretaries with the mem. bers of the committee appointed to superintend the arrangements of this room or repository, we ought to succeed in adding an important and valuable feature to the scientific interest of the mcetings of the Association.

E. RAY LANKESTER

\section{A Waterspout at Milford $\mathrm{H}$ aven}

'I'HE enclosed account of a waterspout which was sent to me by one of our telegraphic reporters may perhaps be of interest to your readers.

ROBER'T H. SCOT'

Aug. I

"St. Ann's Head, Milford Haven, July 28

"Sir,--The waterspout mentioned in this morning's report was observed yesterday at 4.50 P.M., about a mile outside the port, following in the wake of a squall. Its course lay about N.E., and the progressive movement was judged to be between twenty-five and thirty knots per hour. Its diameter at the base was about $40 \mathrm{ft}$., and the direction of the whirl from left to right, or with the hands of a watch. The lower portion was well defined, but the middle and upper portions were not so distinct; in fact, the connection with the clouds above, although undoubtedly existing, could not be discerned from our point of view. The sea immediately under it was greatly agitated and white with foam, the spray ascending in a spiral form. Thunder was heard with the squall that preceded it, and the wind veered from S. to S.S.W., although it backed to S. again afterwards.

$$
\text { "R. H. Scott, Esq." }
$$$$
\text { (Signed) }
$$

JOHN C. WALKER

\section{Periodicity of Rainfall}

MY attention has been recalled to the letter (vol. viii. p. 547) of my old friend Mr. Meldrum, dated Sept. I 5 last, upon the above subject, by its recent republication in a Barbados newspaper. I had intended at the time to examine whether his objections to my statements were valid, but absence from the island and other occupations interfered. On reperusing his letter, I perceive that he notices a disagreement between my figures and those given by Mr. Symons, which requires to be explained, and I take the opportunity of endeavouring to remove his doubts with regard to the correctness of my results. Mr. Symons's annual averages for $1843-61$ were drawn from one station, or rather from two; from Fairfield for the years $1843-46$, and from Halton, a station nearly three miles distant, and having twice the elevation, for the rest of the period. My averages were taken for the first four years from the same single station, the only record then in existence, and from a varying number of stations during the other year's.

Mr. Meldrum thinks that, with certain alterations which he suggests, my calculations will support his theory. I should be very glad if they did. My object in pursuing my inquiries into the rainfall of Barbados has been to assist the planters in forecasting the coming seasons, so as to guide them in their agricultural operations; and I would gladly welcome every contribution to this end, whether it be Mr. Meldrum's sun-spots or Prof. Chase's lunar influences. I was therefore disappointed when I found that the experience of this island did not coincide with that of Mauritius, and I am sorry that a further comparison of the data, which is not open to any objection of discordance of elements, confirms my first calculations.

If I take Fairfield and Halton alone, for the thirty-one years 1843-73, I obtain the following results :-

\begin{tabular}{|c|c|c|c|}
\hline & & Maximun years. & Minimum jears. \\
\hline $1843-45$ & $\cdots$ & $\cdots \quad-$ & 16377 \\
\hline $\mathrm{I} \mathrm{S}_{47} 7-49$ & $\cdots$ & $\cdots \quad 158.3$ & - \\
\hline I $855-57$ & $\cdots$ & $\cdots \quad \cdots$ & $x 70 \%$ \\
\hline $1859-61$ & $\cdots$ & 186.6 & - \\
\hline $\begin{array}{l}\text { I } 866-68 \\
\text { I } 870-72\end{array}$ & $\cdots$ & - & 177.8 \\
\hline $70-72$ & $\cdots$ & $\ldots \quad 157^{\prime} 1$ & - \\
\hline & Total & ... $502^{\circ} \mathrm{O}$ & $512 \cdot 2$ \\
\hline
\end{tabular}

This calculation shows an annual average excess in minimum years of 34 inches. But the rainfall at Fairfield during the last three years, for which alone $I$ have the means of comparison, is 13.33 per cent. below that of Halton. Therefore $21^{\circ} 7$ inches have to be added to the minimum average of $1843-45$, which would increase the above excess to 10.6 inches. If Halton alone be tarken for the five periods, the average of the maxima is $x 67.3$, and that of the minima $174^{\circ} 2$, yielding an excess of minima of 6.9 inches.

A comparison of three stations for I9 years, 1855-73, being the longest comparable period, exhibits the same results. These three stations, Halton, Binfield, and Husbands, are situated in opposite parts of the island, and furnish a fair average of the whole :- -

\begin{tabular}{|c|c|c|c|}
\hline \multirow{5}{*}{$\begin{array}{l}1855-57 \\
\text { I } 859-61 \\
1866-68 \\
1870-72\end{array}$} & & Maxinum years. & Minimum years. \\
\hline & $\cdots$ & $\ldots \quad-$ & 1927 \\
\hline & $\cdots$ & 193.6 & - \\
\hline & $\cdots$ & - & $\mathrm{I} \mathrm{S}_{2} \cdot \mathrm{G}$ \\
\hline & $\ldots$ & I62.7 & $\ldots$ \\
\hline & Total & ... $356 \cdot 3$ & 3753 \\
\hline
\end{tabular}

This calculation show's an annual average excess of 9.5 inches in minimum years, which differs only by $I$ 'I inch from the above corrected calculations founded on the returns of a single station.

Mr. Meldrum, in his letter of September, writes, that I have " taken 1846 and 1871 as middle maxima years [in my first paper I also took 1848 ], whereas $1849-72$ are probably more cor. rect." Mr. Meldrum is in error as to my having taken 1846 as 